\title{
ICONOGRAPHIES OF OCCUPATION
}





\section{ICONOGRAPHIES OF OCCUPATION}

Visual Cultures in Wang Jingwei's

China, 1939-1945

Jeremy E. Taylor

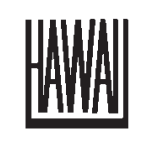

University of Hawai'i Press Honolulu 
The Open Access edition of this book is licensed under Creative Commons Attribution-NonCommercial-NoDerivatives 4.0 International (CC BY-NC-ND 4.0), which means that digital editions of the work may be freely downloaded and shared for non-commercial purposes, provided credit is given to the author. Commercial uses and the publication of any derivative works require permission from the publisher. For details, see https://creativecommons.org/licenses/by-nc-nd/4.0/.

The Creative Commons license described above does not apply to any material that is separately copyrighted.

ISBN 9780824887704 (PDF)

ISBN 9780824887711 (EPUB)

ISBN 9780824887728 (Kindle)

Open Access edition sponsored by the European Research Council.

Advertising poster for Taiwanese green tea (circa 1941) featuring Manchukuo, RNG Chinese and Japanese women, and the flags of these three countries. Courtesy of the National Museum of Taiwan History, Tainan (Image ID 2013.038.0003). 
For my sons 
